\title{
複数ロボットを用いた作業環境の動的形成に関する研究*
}

\author{
福 田 敏 男*1, 宮田明 徳*2, 長谷川 泰久*3
}

\section{Dynamic Construction of Work Environment by Multiple Mobile Robots}

\author{
Toshio FUKUDA, Akinori MIYATA and Yasuhisa HASEGAWA*4
}

${ }^{* 4}$ Department of Micro-Nano Systems Engineering, Nagoya University, Furo-cho, Chikusa-ku, Nagoya-shi, Aichi, 464-8603 Japan

\begin{abstract}
This paper proposes an algorithm of construction and improvement of a work environment by multiple mobile robots. In order to build a system with higher performance, there are two approaches: one is to improve robots' behaviors, and the other is to improve a their environment. In this study, we consider an environment that can be changed easily by robots to improve their task efficiency. Under this environment, it is not important that robots passively adapt their behavior (e.g. Reinforcement Learning), but robots need to actively and cooperatively change their environment. Therefore dynamic potential fields are proposed as a shared memory among robots for their cooperation. In this paper, a warehouse problem in which robots allocate and relocate stocks is introduced as an example of cooperative task of multiple robots. The stock layout in the warehouse is not designed initially, and is not fixed. Under this condition, simulation results show that the proposed algorithm achieves self-organization of stock layout and cooperation among robots according to the given task.
\end{abstract}

Key Words: Multiple Mobile Robots, Dynamic Potential Field, Warehouse Layout, Shared Memory

\section{1.は じめに}

複数ロボットシステムは, 作業の並列性, 故障や環 境変化に対するロバスト性の面から注目されている. 障害物回避 $^{(1)(2)}$, 分散センシング(3), 飭集め行動 ${ }^{(4)(5)}$ などにおいて, ロボットの内部状態を動的に変化させ ることによって作業環境に適応した行動を獲得する研 究は，これまでに数多く報告されている.

環境に受動的に適応する手法としては強化学習が有 名であるが(6)(7), 逆に, ロボットの行動を環境に適応 させるのではなく, 環境を変更する方が有効な場面が 考えられる. 例えば, 移動ロボットの経路上に障害物 が存在する場合に, その経路を何度も往復するのであ れば，先に障害物を除去してしまうことによってその 後に回避行動を行わなくて済むといったことがある. このように，ロボットが作業に応じて積極的に作業環 境を改善するような研究は, 最近になっていくつか研 究され始めた ${ }^{(8)(9)}$.ここで, 作業環境の改善とは, 主目 的の作業を効率良く行うために, ロボットの外部環境

\footnotetext{
* 原稿受付 2003 年 2 月 19 日.

*1 正員, 名古屋大学大学院工学研究科(泰 464-8603 名古屋市 千種区不老町)

*2 名古屋大学大学院工学研究科.

*3 正員, 筑波大学大学院システム情報工学研究科( $\mathbf{w}$ 305-8573 つくば市天王台 1-1-1)

E-mail : fukuda @ mein.nagoya-u.ac.jp
}

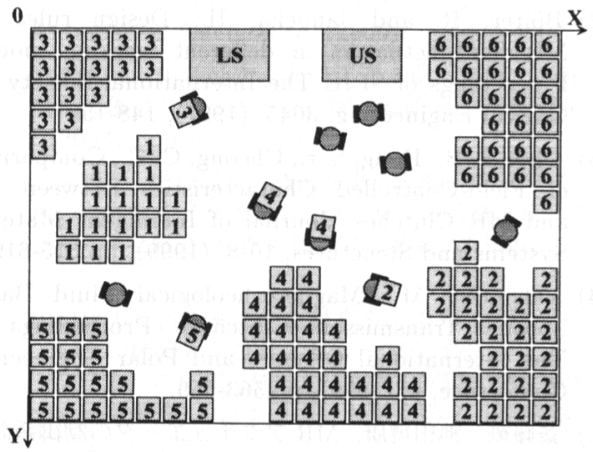

Fig. 1 Multi-robot warehouse system

を変更することを指す. 宮田らは複数台の移動ロボッ トによる大型対象物の協調搬送において，搬送作業と 移動経路を妨害している物体の除去といった異種作業 を動的に割り当てる手法を示している(10). そこでは一 つのロボットグループの視点において, 障害物の除去 を行なっている. しかし, 複数のロボットやロボット グループが別々に並行して作業を行っている場合には, 障害物を他の場所に移動することによって作業を妨げ てしまう恐れがあるため, 実時間で互いの行動を考虑 して環境を変更することが必要であると考えられる。 そこで本研究では, マルチロボット環境におけるロ 
ボットの行動ルールに適した環境条件の自律的な形成 を取り上げ，他のロボットの行動を考虑した適切な協 調関係の確立を目指寸。本研究において取り扱う具体 的な例題として, 図 1 に示すような, 倉庫レイアウト （搬送ロボットの通路，および荷物の保管場所の配置） が事前に決定されていない，任意の場所に荷物が配置 可能な倉庫を考える.この倉庫には数種類の荷物が同 時に保管され，またそれぞれの荷物は倉庫の総床面積 に対して比較的小さいとする，倉庫作業では，荷物の 搬入や搬出といった搬送作業だけでなく保管作業も含 まれるが(11), 本例題ではロボットの通路は明確に決め られておらず，倉庫内に保管された荷物は，動作環境 内の障害物としてロボットの行動に直接影響を与える. そのため, ロボットの搬送作業を妨害しないように, 荷物の配置が決定される必要がある。そこで本論文で は，動作環境内の各座標におけるロボットの移動経路 としての重要度をポテンシャルを用いて表わし，シス テムがこのポテンシャル場を更新することにより適切 な荷物配置を実現することを目的とする.

本研究とは問題設定が異なるが，ポテンシャルを用 いた場の形成について, 従来研究がいくつか提案され ている．例えば，短期記憶に基づく確率的な行動選択 ルールをもつ複数ロボットを用いた，空間内における 物体の種類ごとのクラスターの生成手法が提案されて いるが(12)，そこではロボット間での情報の明示的な共 有がないため, クラスターの形成に多くの時間を要す る. その他の研究としては, 複数ロボットによる資源 収集手法が提案されており ${ }^{(13)}$, 空間内に散らばった資 源をロボットがポテンシャル場に従い回収基地まで効 率的に搬送している。ここでは，資源の搬送目的地は 回収基地の一力所であるが, 本研究で取り扱う例題で は倉庫内に数種類の荷物を搬入するため，荷物の搬送 先は複数存在する。そこで, 本論文では, 荷物の種類 ごとにポテンシャル場を複数用意することで, 本論文 中の倉庫作業モデルにより適した手法一と拡張を行い, また, ロボット間の情報共有により, 短期間でのポテ ンシャル場の形成を実現する.

本論文の構成は次のとおりである。2 章では本論文 で対象とする倉庫作業モデルについて説明する． 3 章 では荷物配置の動的決定手法について説明する.4 章 でシミュレーションにより提案手法の有効性を検証し, 5 章で結論と今後の課題について述べる.

\section{2. 倉庫作業モデル}

$2 \cdot 1$ モデルの概要一般に, 倉庫に格納される 荷物の種別および数量が環境情報として事前に与え

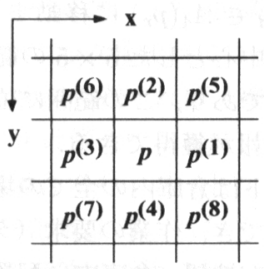

Fig. 2 Adjacent cells

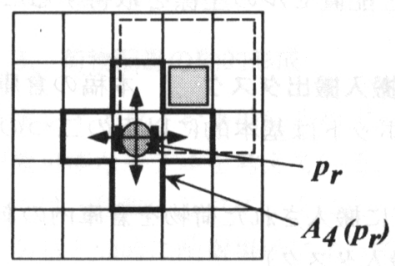

Fig. 3 Action and sensing range

られていれば，その情報に基づき最適な倉庫レイアウ ト（搬送ロボットの通路，および荷物の保管場所の配 置）の決定が可能であると考えられる.しかし，この 環境情報が未知である場合は，事前に倉庫レイアウト を決定することは困難である，そこで本稿では，対象 とする倉庫作業モデルとして，倉庫レイアウトが事前 に決定されていない，任意の場所に荷物が配置可能な 倉庫を考える.そこでは, 荷物は複数の種類に区別さ れており，取り出しやすさを考慮して同種類の荷物を まとめて配置し異なる種類の荷物を分離して配置する といった「仕分け作業」を行う。本節では，この倉庫 作業モデルの概要について説明する.

2.2 作業環境倉庫内には Loading Station(以下 LS) と Unloading Station(以下 US) が 1 個所ずつ設置 してあり，荷物は要求に応じて LS から搬入され，い ったん倉庫内に保管された後，US に搬出される．平 積み倉庫を考え，荷物の上に別の荷物を積み重ねて 配置することはできないとする。荷物の配置場所を 明確にして管理コストを低減するために，倉庫内を 荷物と等しい大きさ程の格子状のセルに分割し, セ ルの座標を $p=(x, y)$ と定義し, $p$ の 4 近傍セル 集合を $A_{4}(p)=\left\{p^{(1)}, \ldots, p^{(4)}\right\} ， 8$ 近傍セル集合を $A_{8}(p)=\left\{p^{(1)}, \ldots, p^{(8)}\right\}$ と定義する (図 2).

荷物は, $K$ 種類 (最大 10 種類程度) 存在し, 種類 $k \in K$ の荷物を $s_{k}$ と表し，また， 1 個の荷物を指定 する場合は $s_{k}(i)\left(i=1, \ldots, m_{k}\right)$ として表す.ここで, $m_{k}$ は倉庫内に存在する $s_{k}$ の個数である.

2.3 作業ロボット 倉庫内で作業を行なうロボッ トの台数は $N$ 台とし, 台数は固定とする.ロボット は荷物を 1 個搬送することができる。 また図 3 のよう に, ロボットは時間 1 step で現在のセル $p_{r}$ から 4 近 
傍セルの一つ $p_{d} \in A_{4}\left(p_{r}\right)$ に移動することができる． またロボットを中心とした $5 \times 5$ の範囲のセルがセン シング可能領域であり，この範囲に位置する荷物や他 のロボットの情報が獾得できる.

なお，ロボットは倉庫内の全ての場所からホストと 通信することができ，作業の要求 (タスク要求) や口 ボット同士の共有情報, 倉庫内に配置されている荷物 の種類と配置セルの座標を取得することができると する.

2.4 搬入出タスク本稿の倉庫モデルにおい て，ロボットは基本的に以下の二つのタスクを実行 する。

・ LS に搬入された荷物を倉庫内のある位置へ配置 (搬入夕スク)

・ ホストから要求された種類 $k$ の荷物をUS へ搬送 (搬出タスク)

搬入・搬出タスクはホストにキューとして蓄えられて おり，ロボットにはキューの先頭のタスクから順に与 えられる，ロボットは 1 つタスクが終了すると，再 びホストに問い合わせて新しいタスクを受け取り,こ れを繰り返す．タスクはロボットに対して 1 度に 1 つ 与えられ，他のロボットに袞ったりロボット同士で交 換することはできない.

搬入・搬出タスクの発生規則は次のとおりである.

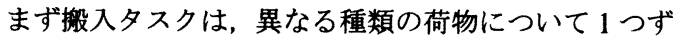
つ順に発生する. また搬出タスクは, 種類 $k$ の荷物に 対して，その種類の荷物の現在の保管量 $m_{k}$ と，あら かじめ決められた荷物の最低保管量との差分がそのま ま搬出要求の数として発生する. 倉庫内にはこの搬入 タスクと搬出タスクの発生規則の違いによるずれが保 管される．ただし，倉庫内の荷物が最大保管数 $M_{\max }$ を超えた場合は，新たな搬入タスク要求が発生しない とする．また，ロボットは以上のタスクの発生規則を 知ることはできない.

搬入・搬出タスクの実行手順を以下に示す.

・搬入タスク： ホストから搬入タスクが与えら れると, ロボットはLSに移動して荷物 $s_{k}(i)$ を 積載する．そして，この荷物と同じ種類の荷物 $s_{k}(j),(j \neq i)$ を倉庫内から選択し，この荷物の 座標 $p_{s_{k}(j)}$ へと向かい移動する.この途中で他の ロボットにより荷物 $s_{k}(j)$ が搬送された場合には, 再び他の荷物を選択する. 荷物 $s_{k}(j)$ の周辺に口 ボットが到達したら, 荷物 $s_{k}(j)$ 周辺の空白セル の一つに荷物 $s_{k}(i)$ を配置する（空白セルの選択 方法は 3.2.2 節）。
・㩔出タスク : ホストから搬出タスクが与えられた 場合には, 搬出要求のあった種類 $k$ の荷物 $s_{k}(i)$ を倉庫内から一つ選択し，この荷物の座標 $p_{\boldsymbol{s}_{k}(i)}$ へと向かい移動する.この途中で他のロボットに より荷物 $s_{k}(i)$ が搬送された場合には，再び他の 荷物を選択する: 座標 $p_{s_{k}(i)}$ 一移動した後, ロボッ トは $s_{k}(i)$ を積載し US に搬送する.

以上のタスクの遂行において, 各ロボットはLS, US, もしくは倉庫内の選択された荷物 $s_{k}(i)$ などの目的地 まで移動する必要がある．本稿では简単のため,この ときのロボットの移動方向 $p_{d} \in A_{\mathbf{4}}\left(p_{r}\right)$ の決定方法と して, 目的地とロボットとの距離が堿少する方向のセ ルが選択されるよう定める。

2.5 荷物の再配是タスク本稿の倉庫モデルで は, 初期の段階において荷物配置は未形成であり，前 節の搬入・搬出タスクの遂行により，荷物配置は段階 的に形成されていく，その形成過程において乱雑な荷 物配置が現れることがあるが，搬入・搬出タスクの実 行のみではこの乱雑な配置はなかなか解消されない. よって，各ロボットが倉庫内の荷物を積極的に再配置 する必要がある.

荷物を搬送していないロボットの 4 近傍セル $A_{4}\left(p_{r}\right)$ に荷物が配直されているとき，ロボットは確率 $\eta$ でこ の荷物の再配直を行う。ここで $\eta$ は再配置確率と定義 され，本稿では定数として事前に与えられるものとす る. 具体的な再配珇の手順を以下に示す.

・再眍目タスク：確率 $\eta$ でロボットは 4 近傍セル $A_{4}\left(p_{r}\right)$ に配置される荷物 $s_{k}(i)$ を一つ積载する. そして, この荷物と同じ種類の荷物 $s_{k}(j),(j \neq i)$ を倉庫内から選択し，この荷物の座標 $p_{\boldsymbol{s}_{\boldsymbol{k}}(j)}$ 人と 向かい移動する．この途中で他のロボットにより 荷物 $s_{k}(j)$ が搬送された場合には，再ひ他の荷物を 選択する. 荷物 $s_{k}(j)$ の周辺にロボットが到達した ら, 荷物 $s_{k}(j)$ 周辺の空白セルの一つに荷物 $s_{k}(i)$ を配置する（空白セルの選択方法は 3.2.2 節）。 なお，選択された荷物 $s_{k}(i)$ までの移動経路の決定は， 前節と同様に行なう。

2.6 合庫内の荷物の逞规 2.4 節および 2.5 節で 述べたように

-「搬入タスク」および「再配置タスク」(case 1)

-「搬出タスク」(case 2)

のそれぞれのタスクを実行する場合において，ロボッ トは倉庫内から荷物を一つ選択する. case 1 の場合は, 同種類の荷物をまとめて配直するために，荷物重心 $G_{k}$ に近い荷物を選択する．また case 2 の場合は，荷物の まとまりが分㱋しないように，荷物重心 $G_{k}$ から遠い 


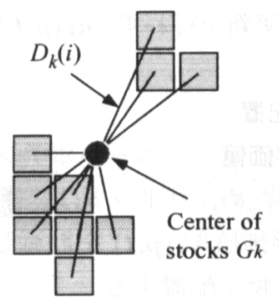

Fig. 4 Center of stocks

荷物を選択する.

種類 $k$ の各荷物の座標を $p_{s_{k}(i)}=\left(x_{k i}, y_{k i}\right)$ とする と, 荷物重心 $G_{k}$ は

$$
G_{k}=\left(\frac{1}{m_{k}} \sum_{j=1}^{m_{k}} x_{k j}, \frac{1}{m_{k}} \sum_{j=1}^{m_{k}} y_{k j}\right)
$$

となる (図 4). ここで, $G_{k}$ から $p_{s_{k}(i)}$ への距離を $D_{k}(i)$ とする. $D_{k}(i)$ が最も大きい荷物, もしくは最も小さ い荷物をターゲットとして選択するとその荷物に複数 のロボットが集中し, 搬送効率が低下するため, ター ゲットの選択をボルツマン分布に従った確率によって 行う。つまり, 倉庫内からターゲットとして $s_{k}(i)$ を 選択する確率 $q\left(s_{k}(i)\right)$ は,

$$
q\left(s_{k}(i)\right)=\frac{\exp \left(\frac{w_{k}(i)}{\tau}\right)}{\sum_{j=1}^{m_{k}} \exp \left(\frac{w_{k}(j)}{\tau}\right)}
$$

となる.ただし, $\tau$ は温度定数であり, $w_{k}(i)$ は,

$$
w_{k}(i)= \begin{cases}\max _{j}\left\{D_{k}(j)\right\}-D_{k}(i) & \text { in case } 1 \\ D_{k}(i) & \text { in case } 2\end{cases}
$$

である。

2.7 デッドロックの回避前節までに述べたよ うに, LS, US, もしくは倉庫内の選択された荷物 $s_{k}(i)$ などの目的地までの移動において, 各ロボットは最短 経路を選択する.よって, そのときの荷物配置によっ てはロボットの経路が他の荷物に遮られ, デッドロッ ク（もしくはライブロック）に陥る可能性がある.こ の回避の方法について以下に述べる.

デッドロックはロボット自身が検出し, ロボットが一 定ステップ中に一定回数同じセルを通った場合はデッ ドロック（またはライブロック）であるとみなす. デッ ドロックが検出されたときには, ロボットは一定ステッ プ間ランダムウォークを行い, デッドロックの回避を 行う.

また, ロボットが種類 $k$ の荷物を積載している場合 には, ロボットがその場に荷物を配置し, 搬送タスク
を放棄することでもデッドロックが回避できる.よって この場合は, デッドロック検出時に 4 近傍セル $A_{4}\left(p_{r}\right)$ に同じ種類 $k$ の荷物が存在すれば，確率 $\alpha_{1}$ で荷物を 配置する。また, 4 近傍セル $A_{4}\left(p_{r}\right)$ に同じ種類 $k$ の 荷物が存在しない場合でも, デッドロックを検出すれ ば確率 $\alpha_{2}$ で荷物を配置する.ただし， $\alpha_{1}>\alpha_{2}$ とす る.これは種類 $k$ の荷物の近傍であれば配置を許容し, そうでなければ配置を抑制するためである.

\section{3. 荷物配置の動的形成}

本稿では，倉庫レイアウトを事前に決めず，荷物を 任意の場所に配置可能なモデルを考えている.このよ うな環境においては, 移動するロボットにとって各荷 物は作業対象であると同時に配置場所によっては障害 物にもなりらるため, 2.4 節および 2.5 節で述べた「搬 入タスク」と「再配置タスク」において, 荷物の配置 場所は適切に選択されなければならない. また, 2 章 で述べたように，ロボットの行動を決定するルールは 基本的に固定であるため, ロボットの移動を妨害する 位置に荷物が配置された場合， 2.5 節および 2.7 節で 述べた「荷物の再配置」や「デッドロックの回避」に 多くの時間が費やされて, システム全体の効率を下げ る結果となる.よって, システムの効率向上のため, ロボットの移動経路を確保しつつ, 適切な荷物配置を 決定する必要がある.

このとき, 各ロボット個体の視点で移動経路の確保 を行なうと, 他の種類の荷物を搬送するロボットの移 動を阻害することが考えられる. そこには, 他のロボッ トとの適切な協調関倸を確立する仕組みが必要である と考えられる.よって以下の節では, 移動経路の確保 のためのルートポテンシャルの形成と, それを利用し た荷物の配置場所の決定方法について述べる.

3.1 移動経路の確保 まず, 図 5 に示すように, ロボットは進行方向のセル $p_{d} \in A_{4}\left(p_{r}\right)$ を経路要求と してホストに通知する.これは, $p_{d}$ に荷物が配置され ている場合に, 荷物の配置セル上に経路要求を発生さ せるためである. ホスト上において, 各セル上の経路 要求の有無は

$$
\delta_{k}(p, t)= \begin{cases}1 & \text { if route demand exists at } p \\ 0 & \text { otherwise }\end{cases}
$$

と表わされる.ここで, $p$ はセルの座標, $t$ は時刻で ある.

続いて, 複数の荷物が連なって配置されている場合 には, 経路を妨害している荷物のみを排除するのでは なく, 周囲の荷物から順次移動させることが有効であ るため, 経路要求を拡散方程式によってその周辺に拡 


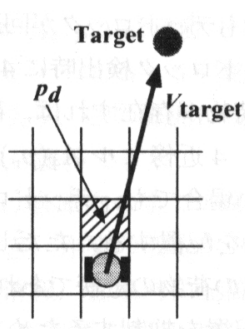

Fig. 5 Route demand

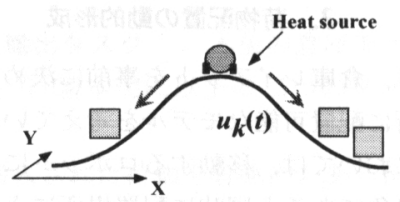

Fig. 6 Route potential

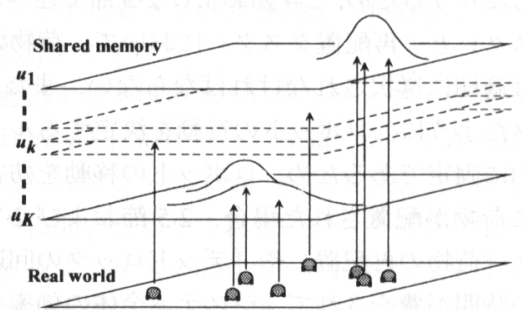

Fig. 7 Potential fields on shared memory

散させる (図 6).この経路要求の拡散によって, 図 7 のように, 荷物の種類ごとにポテンシャル場がホスト の共有メモリ上に形成される。このポテンシャルを指 標として, ロボットが高い頻度で利用する移動経路を 優先的に保持することで, 荷物にロボットの経路が遮 られることのない適切な荷物配置が短期間で形成され ることが期待できる．ここでは，このポテンシャルを ルートポテンシャル $u_{k}(p, t) \in[0,1]$ と呼び, この更新 則を次式のように定める.

$$
\begin{aligned}
\left(u_{k}(p, t\right. & \left.+\Delta t)-u_{k}(p, t)\right) / \Delta t \\
= & \kappa\left\{\sum_{a=1}^{4} u_{k}\left(p^{(a)}, t\right)-4 u_{k}(p, t)\right\} \\
& +\delta_{k}(p, t) h_{1}\left(1-u_{k}(p, t)\right)-h_{2} u_{k}(p, t)
\end{aligned}
$$

ただし， $\kappa$ は拡散係数, $h_{1}, h_{2}$ は熱交換係数, $\Delta t$ は 1 step を指す.なお, 上式の境界条件は傾きゼロのノイ マン境界条件とする. 式（5）の第1 項は拡散項であ る. 第 2 項は発熱項であり, 経路要求 $\delta_{k}$ が熱源とな り, その経路が温められることを示している. 第 3 項 は吸熱項であり, 熱の飽和を防ぐためのものである.

式 (5)によるルートポテンシャル $u_{k}$ の更新は, 経路 要求 $\delta_{k}=1$ のときにのみ行われる. $\delta_{k}=0$ である荷物 の種類 $k$ に関しては, 現状のルートポテンシャルの形状
を維持するため更新を行わず, $u_{k}(p, t+\Delta t)=u_{k}(p, t)$ となる。 1

\section{2 荷物の配置}

3.2:1 環境評価値、ルートポテンシャルによる移 動経路の確保のため, ロボットは座標 $p$ のセルについ て以下の環境評価値 $V_{k}(p, t)$ を計算し, $V_{k}(p, t)$ がよ り高いセルに荷物を配置する。

$$
\begin{aligned}
& V_{k}(p, t)= \\
& \varepsilon(p, t) \phi_{k}(p, t)\left\{\gamma_{k}(p, t)+\frac{1}{K-1} \sum_{\substack{j \in K \\
j \neq k}}\left(1-u_{j}(p, t)\right)\right\}
\end{aligned}
$$

ここで

$$
\begin{aligned}
\varepsilon(p, t) & = \begin{cases}1 & \text { if } s_{k}(\text { for all } k) \text { doesn't exist at } p \\
0 & \text { otherwise }\end{cases} \\
\phi_{k}(p, t) & = \begin{cases}1 & \text { if } s_{k} \text { exists in } A_{4}(p) \\
0 & \text { otherwise }\end{cases} \\
\gamma_{k}(p, t) & = \begin{cases}1 & \text { if } s_{k^{\prime}}\left(\text { for } k^{\prime} \neq k\right) \text { doesn't exist in } A_{8}(p) \\
0 & \text { otherwise }\end{cases}
\end{aligned}
$$

である. 式(6)において, $p$ に荷物がすでに配置されて いる場合や $k$ の荷物の近傍でない場合は最小值 0 とな る. また, 近傍セルに種類 $k^{\prime},\left(k^{\prime} \neq k\right)$ の荷物が存在 する, または種類 $k$ 以外に対応するルートポテンシャ ルの和が高いセルについては, 評価値 $V_{k}(p, t)$ は低い 值を示す.これは, 種類 $k$ の荷物がこのセルに配置さ れることを抑制し, 他の種類 $k^{\prime}$ の荷物の搬送経路が 保持されることを意味する.

\subsection{2 配置手順「搬入タスク」および「再配置} タスク」において, 環境評価值 $V_{k}(p, t)$ の高いセルに 荷物を配置するために, ロボットは図 8 に示すように, (a) 選択された荷物周辺への移動, (b) 配置昜所の決定, といった段階的な手順によって配置を行う。2

(a) 選択された荷物 $s_{k}(i)$ に向かって, ロボットは移動 を行う。ここでは同種類の荷物がまとめて配置さ れれば良いため, 必ずしもロボットが座標 $p_{s_{k}(i)}$ に到達寸る必要はない，ロボットが種類 $k$ の荷物 が配置されているセル $p_{s_{k}}$ の8近傍セル $A_{8}\left(p_{s_{k}}\right)$ に到達したならば, (b)に移る.

(b) 荷物に沿って環境評価値がより高いセルに移動を 行い, 環境評価值の最大值に到達したら荷物を配

1ルートポテンシャルの形成に必要となる計算量は, 合庫内の総 七ル数 $S$ と荷物の種類 $K$ を用いて $O(S K)$ となる.

2 この荷物の配置に必要な計算量は $O(K)$ となり, 作業全体の 計算量は, ルートポテンシャルの形成に行われる計算が支配的とな る.よって, ロボット 1 台あたりの計算量は, $O(S K)$ となる. 


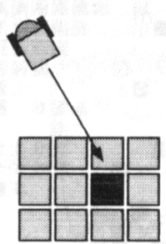

(a) Move to the target stock

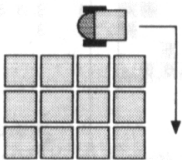

(b) Move along the stocks toward potential minima
Fig. 8 Procedure of stock allocation

置する.まず，ロボットは近傍セル $A_{8}\left(p_{r}\right)$ の中 から最も環境評価値が高いセル $\hat{p}_{r}$

$$
\hat{p}_{r}=\arg \max _{p_{r}^{(a)} \in A_{8}\left(p_{r}\right)}\left\{V_{k}\left(p_{r}^{(a)}, t\right)\right\}
$$

を計算する. 次に $V_{k}\left(\hat{p}_{r}, t\right)>V_{k}\left(p_{r}, t\right)$ であれば， $\hat{p}_{r}$ に移動を行い，これを繰り返す. $V_{k}\left(\hat{p}_{r}, t\right) \leq$ $V_{k}\left(p_{r}, t\right)$ であれば, $p_{r}$ に荷物を配置する。

なお, 倉庫内に $k$ の荷物が存在しない場合は, ランダ ムなセルに荷物を配置することにする。

$$
\text { 4. シミュレーション }
$$

$4 \cdot 1$ 条件設定 シミュレーションの条件を下記 のとおり設定し, 20000 step までシミュレーションを 行う.

[シミュレーション条件]

・ロボットの台数 $N$ は 10 台

- 倉庫内を $[20 \times 15]$ の格子状のセルに分割

・ LS およびUS は 1 個所ずつ設置

- 荷物の種類数 $K$ は 6 種類, 最大保管数 $M_{\max }$ は 120 個.

・ルートポテンシャルのパラメータは, $\kappa=$ $0.002, h_{1}=0.02, h_{2}=0.001$

・デッドロック検出時の荷物配置確率は, $\alpha_{1}=$ $0.8, \alpha_{2}=0.2$

- 再配置確率 $\eta=0.3$

以上のシミュレーション条件において，システムの 効率評価は「時間あたりの達成回数」により行う。こ こで，時間当たりの達成回数は，100 step 間に搬入夕 スクと搬出タスクを達成した回数の合計とする.

本シミュレーションでは, 次の 3 項目について評価 を行う.

（1）荷物の配置形状の遷移と時間当たりの達成回数, 再配置を行なっているロボットの台数比率。ここ で, 台数比率は, ロボット全台数のうち 100step

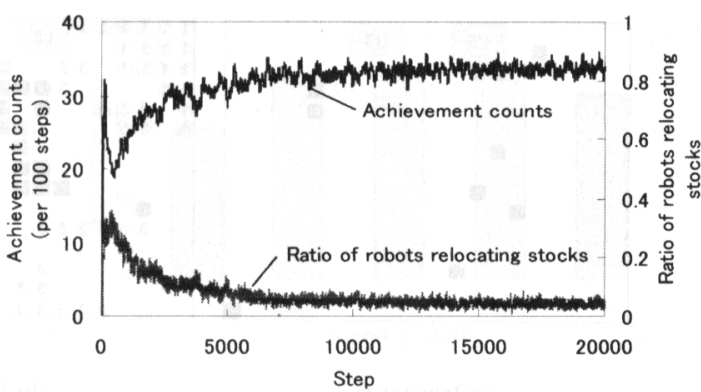

Fig. 9 Ratio of robots relocating stocks

間に再配置を行ったロボット台数の比とする.

（2）荷物の最大保管数の違いによる時間当たりの達成 回数の変化. 最大保管数 $M_{\max }$ を, 40 から 200 個まで変化させた場合の時間当たりの達成回数を 比較する。

（3）ロボット間で情報共有の有無によるルートポテン シャルの形成速度. 情報共有を行なわない場合と 比較して短期間で移動経路を妨害しない荷物の配 置形状が形成されるかを検証する，情報共有を行 なわない場合はルートポテンシャルを各ロボット が独自に形成する。

\section{2 結果および考察}

4.2.1 荷物配置形状の遷移と時間当たりの達成回数 図 10 に 3000 step までの荷物配置のスクリーンショッ トを示す．図中の濃いグレーの角が丸い四角はロボッ 卜を示しており，中に白丸が描かれている場合は荷物 の搬送中を示している。.上部の大きな四角は LS と US を示しており，中に数字が描かれている四角が各種類 の荷物を示す.また，図 9 に時間当たりの達成回数と 荷物の再配置を行っているロボットの台数比率の推移 を示す.

シミュレーション初期から $200 \mathrm{step}$ 付近までは，倉 庫内に荷物が存在していない状態から開始しているた め，妨害する荷物が少なく搬入タスクが容易に行われ， 搬送効率が高い，その後，ある程度，倉庫内に荷物が 搬入されると，時間当たりの達成回数は約 18.9 回/100 steps まで低下した。これは，荷物の配置場所とロボッ トの移動経路の分離が出来ておらず，結果的にロボッ トの移動経路が荷物によって阻害されているからであ る.この時，荷物を搬送していないロボットが同様に 荷物と衝突する回数も多くなり, 頻繁に荷物の再配置 が促進される．500step 付近では，再配置を行うロボッ トの台数比率は約 3 割に達している. その後, 徐々に ルートポテンシャルが明確になると同時に再配置を行 

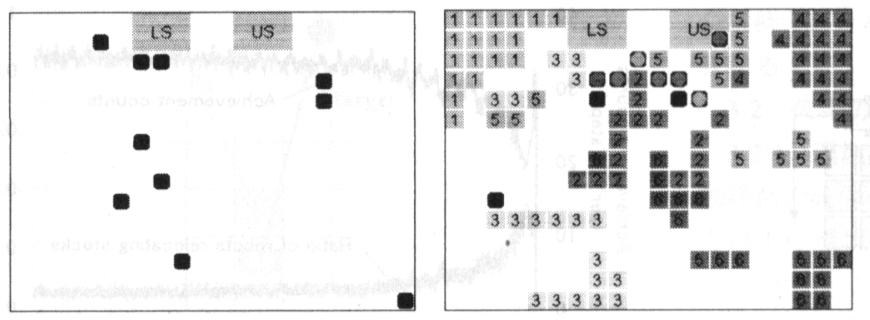

(a) Initial state

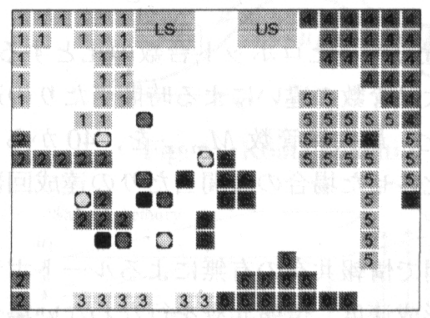

(d) 1500 step (b) 500 step

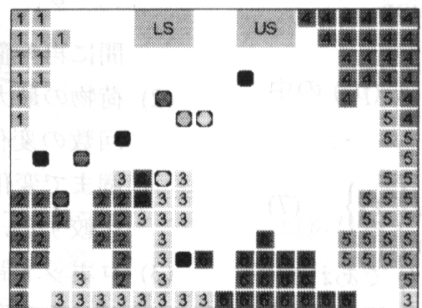

(e) 2000 step

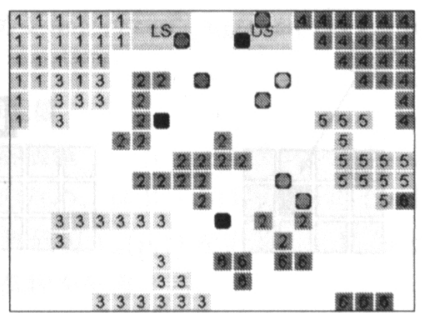

(c) $1000 \mathrm{step}$

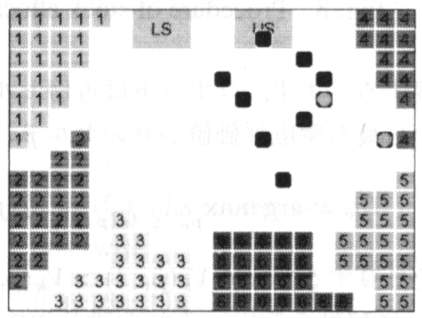

(f) 3000 step

Fig. 10 Transition of stock allocation

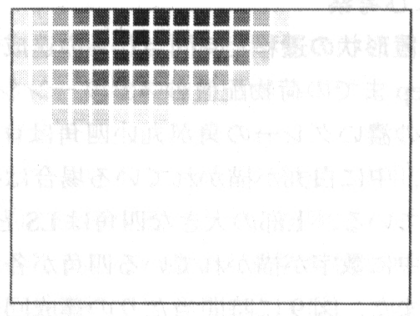

(a) $k=1$

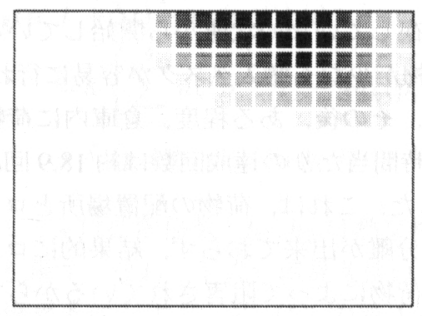

(d) $k=4$

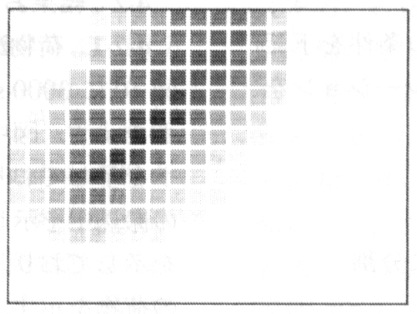

(b) $k=2$

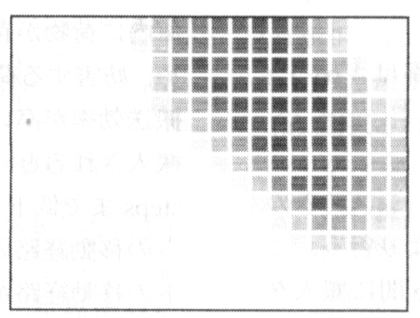

(e) $k=5$

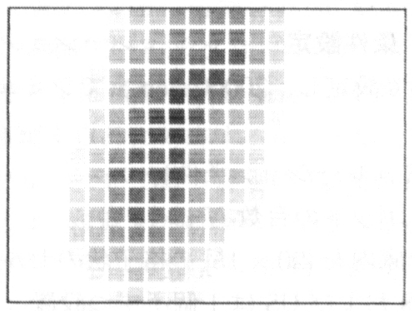

(c) $k=3$

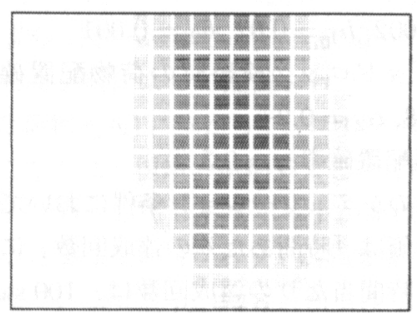

(f) $k=6$

Fig. 11 Route potentials on each stock type (3000 step) 


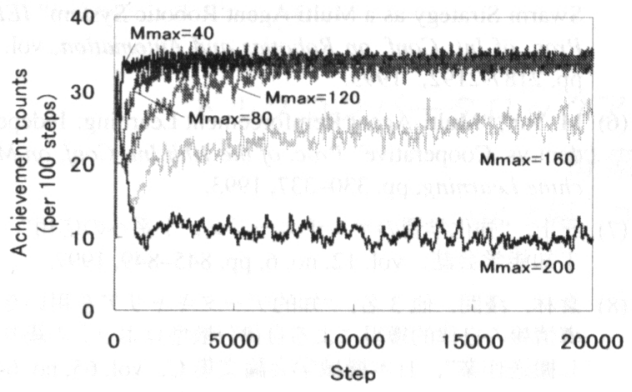

Fig. 12 Performance comparison of the maximum number of stocks

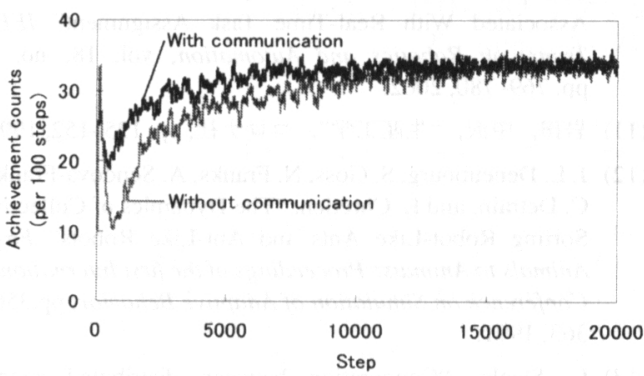

Fig. 13 Performance comparison between system with communication and without communication

うロボットの台数比率も减少し，3000 step において荷 物が種類毎にまとまり移動経路を妨害する荷物が少な くなるような荷物の配置形状を形成された。図 11 に 3000 step 時のルートポテンシャルの形状を示す．濃 淡が濃いほど高い值を表している。また，このルート ポテンシャルの形状から, 交通の激しい中央を避けて 扇状に広がって荷物が配置されている。最終的には， 19000〜20000 step において時間当たりの達成回数は 約 33.8 回/100 steps まで増加し, 再配置を行っている ロボットの台数比率は約 $4.3 \%$ に低下している。つま り，ロボットは搬入搬出タスクに専念できていること がわかる. また，この時点での1台のロボットが $1 つ$ のタスクを達成するために要する時間は約 30.1 step で あるので, 倉庫のサイズ $([20 \times 15])$ から判断して, 搬 入タスクおよび搬出タスクの往復に要する時間として は妥当な結果であると考えられる。

4.2.2 最大保管数による時間当たりの達成回数変化 図 12 では，最大保管数を 40 個から 200 個まで変化さ せた場合における時間当たりの達成回数の変化を示す.

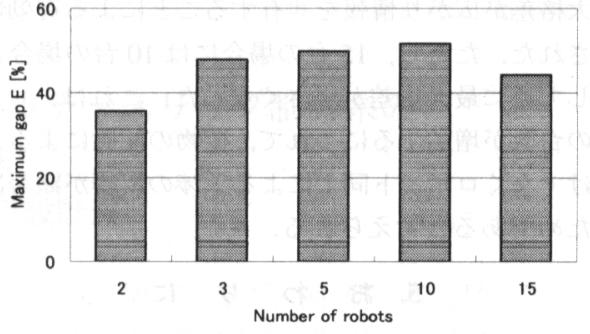

Fig. 14 Maximum gap between system with communication and without communication

これより, 最大保管数が 120 個までは, 時間当たりの 達成回数が約 33 回/100 steps を維持し，120 個以上で は，移動経路を妨害しないように荷物を配置すること が困難になり，時間当たりの達成回数は低下する。こ の最大保管数が 120 個であるとき, 荷物の配置可能面 積に対する荷物の占有率は約 $42.3 \%$ である。 また，最 大保管数が少ないほど, ルートポテンシャルの形成が 短期間で行え, 達成回数が上限に達している.

4.2.3 情報共有の有無による比較 図 13 では, ロボット間で情報共有を行った場合と行わない場合と の時間当たり達成回数の比較を示す. シミュレーショ ン初期の荷物の配置形状が流動的で各ロボットの行動 が定まっていない状態において, 情報共有を行わない 場合は個々の判断で荷物を配置および再配置を行うた め, 互いの移動経路を妨害するように荷物を配置し, 時間当たりの達成回数は低くなった。このとき, 情報 共有を行う場合と比較して 600 step 付近において式 (8) で定義される最大格差 $E$ は $50.8 \%$ あっった.

$$
E=\max _{t}\left\{\frac{e_{1}(t)-e_{2}(t)}{e_{1}(t)} \times 100\right\}
$$

$e_{1}(t)=$ [共有ありの時間当たりの達成回数 $]$

$e_{2}(t)=[$ 共有なしの時間当たりの達成回数 $]$

その後, 荷物の配置形状が徐々に定まると個々の行 動の差が小さくなるため, 個々の判断においても互い の移動経路を妨害しないように荷物の配置を行ってい る.しかし，時間当たりの達成回数が情報共有を行う 場合と同等の值を得るためには 10000 step 以上を要す ることより，情報共有を行うことによって短期間で移 動経路を妨害しない荷物の配置形状を形成できること が示された.

また，ロボットの台数を 2 台から 15 台まで変化さ せた場合の最大格差 $E$ の変化を図 14 に示す。これよ り, ロボットの台数が 10 台までは, 台数が多いほど 
最大格差が広がり情報を共有することによる有効性が 示された．ただし，15台の場合には 10 台の場合と比 較して逆に最大格差が小さくなった。これは，ロボッ トの台数が増加するにつれて，荷物の配置による干涉 だけでなくロボット同士による干涉の影響が顕著にな るためであると考えられる.

\section{5.おわりに}

本論文では, 複数ロボットにおける行動ルールに適 した環境条件の自律的形成の実現を目指し，倉庫作 業モデルを例に挙げ，他のロボットの行動を考虑した 適切な協調関係の確立を行った. 倉庫レイアウトが事 前に決定されていない倉庫作業において，ロボットの 通路と荷物の配置場所を決定するポテンシャル場が, 提案手法により自律的に形成されることを数値シミュ レーションにて確認した．また，そのポテンシャル場 がロボット間の情報共有により比較的短時間で獲得さ れることや，荷物総数やロボット台数の変化に対する 作業効率への影響を確認した.

本論文の提案手法はヒューリスティックに基づくも のであるため, 最適な結果が必ず得られることは保証 できない，今後は，提案手法の数理的・解析的な考察 が必要であると考えられる. また，簡単化のため，本 論文ではロボットの行動ルールを固定としたが，動作 環境とロボットの行動の双方を同時に改善することに より，作業のより効率化が期待される．そこで，動作 環境とロボットの行動ルールの相互発展系モデルの構 筑についても，あわせて今後の課題としたい。

\section{文献}

(1) T. Siméon, S. Leroy, et al., "Path Coordination for Multiple Mobile Robots: a resolution complete algorithm" IEEE Trans. on Robotics and Automation, vol. 18 , no. $1,1999$.

(2) S. M. LaValle, S. A. Hutchinson, "Optimal Motion Planning for Multiple Robots Having Independent Goals" IEEE Trans. on Robotics and Automation, vol. 14, no. 6, pp. 912-925, 1998.

(3) A. Cai, T. Fukuda, et al., "Cooperative Path Planning and Navigation Based on Distributed Sensing" IEEE Proc. of Int. Conf. on Robotics and Automation, vol. 3, pp. 20792084, 1996.

(4) M. J. Mataric, "Designing and Understanding Adaptive Group Behavior", Adaptive Behavior, vol. 4, no. 1 , pp. 51-80, 1996.

(5) N. Mitsumoto, T. Fukuda, et al., "Micro Autonomous Robotic System and Biologically Inspired Immune
Swarm Strategy as a Multi Agent Robotic System" IEEE Proc. of Int. Conf. on Robotics and Automation, vol. 2, pp. 2187-2192, 1995.

(6) M. Tan, "Multi-Agent Reinforcement Learning: Independent vs. Cooperative" Proc. of the 10th Int. Conf. on Machine Learning, pp. 330-337, 1993.

(7) 三上, “強化学習のマルチエージェント系への応用”, 人 工知能学会誌, vol. 12, no. 6, pp. 845-849, 1997.

（8）含林，溇間, 他 3 名, “知的データキャリアを用いた誘 導情報の自律的獲得による自律分散型ロボットの綝り返 し搬送作業”，日本機械学会論文集 C, vol. 65, no. 640, pp. 4744-4749, 1999.

（9）小西，合林，他 2 名，“自律移動ロボットの動作噮境整 備のための分散型情報管理システム配圈設計”, 電気学 会論文誌 C, vol. 120, no. 5, pp. 641-647, 2000.

(10) N. Miyata, J. Ota, et al., "Cooperative Transport by Multiple Mobile Robots in Unknown Static Environments Associated With Real-Time Task Assignment" IEEE Trans. on Robotics and Automation, vol. 18, no. 5, pp. 769-780, 2002.

(11) 岩田, 中沢, “生産工学”, コロナ社, pp. 125-152, 1999.

(12) J. L. Deneubourg, S. Goss, N. Franks, A. Sendova-Franks, C. Detrain, and L. Chretien, "The Dynamics of Collective Sorting Robot-Like Ants and Ant-Like Robots" From Animals to Animats: Proceedings of the first International Conference on Simulation of Adaptive Behavior, pp.356$363,1991$.

(13) L. Steels, "Cooperation between distributed agents through selforganization" Decentralized A.I.: Proceedings of the first European Workshop on Modelling and Autonomous Agents in a Multi-Agent World, pp.175-196, 1990. 